\title{
Composition and Quality of Freshwater Lake Sediments (Balvu and Pērkonu Lakes)
}

\author{
Oskars Purmalis \\ University of Latvia \\ Department of Environmental Sciences \\ Riga, Latvia \\ oskars.purmalis@1u.lv
}

\author{
Linards Kḷaviṇšs \\ University of Latvia \\ Department of Environmental Sciences \\ Riga, Latvia \\ linards.klavins@lu.lv
}

\author{
Lauris Arbidans \\ University of Latvia \\ Department of Environmental Sciences \\ Riga, Latvia \\ lauris.arbidans@lu.lv
}

\begin{abstract}
Water quality, watershed basin and urbanization are key factors from the perspective of freshwater management; however, actual depth of waterbodies is often an overlooked element. Actual depth represents the overall depth of lake bed and depth of sediments. Some cases have been reported, where with increase of average depth of lake, it is possible to expect improvements of water quality when sediments are removed. If lakes are eutrophic, shallow, overgrown with macrophytes and contain high concentrations of biogenic elements water and lake ecosystem quality can be endangered. Removal of sediments can be an expensive procedure and also depends on the composition, structure, local conditions and total amount of sediments, also the disposal or possible use of sediments must be considered. Therefore, it is crucial to understand not only the genesis of sediments, but also possible pollutants, especially in urban territories. Two lakes in Latvia, where the coastal areas of lakes are urbanized at different levels, were studied. Lake Pērkonu was less affected from urbanization than Lake Balvu, cumulative effects of sedimentation and eutrophication were shown as these two lakes are interconnected. Characterization of lake sediments was done, including measurements of $\mathrm{pH}$, ash content, analysis of $\mathrm{C} / \mathrm{N}$ ratio, biological composition, metals, polyaromatic hydrocarbons (PAH), content of organic matter and concentration of humic acids. Results show that structure and composition of sediments in studied lakes differ with increasing depth, giving opportunity to track environmental changes in the past and differentiate possible applications of sediments. In deeper layers sediments were mostly formed from algae, but in more recent stages of lake development macrophytes were more dominant. Sediments formed after Ice-Age and located close to the bottom of the lake differ from conditions on paste (relief of lake bed, streams etc.), because areas with accumulated clay material and areas with sandy material were present.
\end{abstract}

Keywords-eutrophication, dredging, lake sediments, pollution.

\section{INTRODUCTION}

Lake ecosystems provide valuable economic and recreational resources for humans and play important role in regional, environmental and ecological issues, such as hydrological cycles, element biogeochemical cycles and growth of wetland vegetation [1]. In addition, water level and its fluctuations could influence the biodiversity patterns and functions in lake ecosystems [1] - [3]. In shallow lakes, where overgrowing with macrophytes are pronounced, and can affect the lake ecosystem, these factors have to be controlled. Increase of macrophyte biomass, particularly reed biomass, can be correlated with eutrophication [4].

Although, macrophytes influence the functioning of water ecosystems, they also play a crucial role in the mobilization, transportation and accumulation of nutrients, limiting the resuspension of sediments [5]. They are responsible for reduction of penetrating pollutants from the catchment area to the pelagial zone, as they absorb and inactivate a variety of compounds (nutrients, metals), removing them from the water column [6]. Thus, pollutants and nutrients are accumulated in sediments, the photosynthetically active radiation is limited to the littoral sediments, and the resulting effects can lead to increased eutrophication and degradation of shallow lakes [7]. These findings have significant importance for freshwater management of urban lakes, where, under intense human activity, water quality can decrease. It can happen due to the appearance of cyanobacterial blooms, pathogenic bacteria, pollutants and nutrients that may result from an influx of sewage, surface runoff and storm waters [8].

Without the described factors, important element cycles being discussed as part of water chemistry are nitrogen $(\mathrm{N})$ and phosphorus $(\mathrm{P})$ cycles. Even after decreasing external loads of nutrients, especially $\mathrm{P}$ can affect shallow lake ecosystems for decades with their cycling between sediments and the overlying water column [9]. Several methods for reducing the amount of $\mathrm{P}$ exist, but most of them are solid phase P-sorption products including industrial by-products and naturally occurring or modified mineral complexes designed to remove soluble phosphorus through sorption into solid state material [9] - [11]. Rapid regeneration of lakes has been reported in cases where, both, catchment derived and internal P loading have been controlled simultaneously or sediment removal was applied [12].

Sediments are accumulating in the lakes during long periods of time, they are formed from remains of organisms living in the lake and its surroundings, and mineral material supplied to the lake from catchment area and atmosphere [1], [3]. In the freshwater bodies,

Print ISSN 1691-5402

Online ISSN 2256-070X

http://dx.doi.org/10.17770/etr2019vol1.4129

C 2019 Oskars Purmalis, Linards Klaviň̌, Lauris Arbidans.

Published by Rezekne Academy of Technologies.

This is an open access article under the Creative Commons Attribution 4.0 International License. 
sediments (sapropel, gyttja) are formed from aquatic plants, plankton and benthic organisms which are transformed by bacteria, and mixed with mineral components from atmosphere deposition [3]. Sediment types are often classified by their physical features or chemical composition, however, anthropogenic events can have considerable impact on these factors [1]. Excavated sediments have potential for different applications giving opportunity to restore lake environment by applying sediment removal methods [13].

Although accelerated eutrophication and requirements of the Water Framework Directive impose searching for effective restoration methods [11], sediment removal is not used frequently [14], [15] due to the different quality of sediments [16] and environmental risks which include influencing and destroying water ecosystem in the particular area [5]. Nevertheless, the applied recultivation actions have been studied and show different success rates and activity costs, most of the studies show necessity to continue activities for several years [11]. Excavation of sediments is believed to change or significantly affects the ecosystem, however, it is believed, that in the studied lakes it can lead to rapid regeneration of natural ecosystem with increased water quality, without the use of chemicals or solid phase sorption products [9] - [10].

Before removal of sediments, it is crucial to understand not only the genesis of sediments, but also contamination with possible pollutants, especially in urban territories. The aim of the following work is to characterize lake sediments of two lakes in Latvia with accumulated sediments, which are affected by anthropogenic influence.

\section{Materials AND METHODS}

Balvu Lake "Fig. 1" is located in NE Latvia with area $-1.68 \mathrm{~km}^{2}$ and average depth $-2.2 \mathrm{~m}$ (max - 3.9 $\mathrm{m})$ and catchment area $-248 \mathrm{~km}^{2}$. Pērkonu Lake is located in NE Latvia with area $-2.28 \mathrm{~km}^{2}$ and average depth $-1.3 \mathrm{~m}(\max -3.0 \mathrm{~m})$ and water from Pērkonu is flowing to Lake Balvu. They have Pleistocene glacial origin, they are connected and outflowing, indicating strong sedimentation rates in the particular watershed basin. This phenomenon is pronounced in Pērkonu Lake, which is the first waterbody with decreased water flow, and therefore with accelerated sedimentation. The lowest water depth was detected in Pērkonu Lake close to Lake Balvu due to human actions (dredging) in river (Bolupe River) hydrological cycle in the 60-ies of last century, water level of studied exoreic lakes was decreased by 1.5 $\mathrm{m}$, accelerating growth of macrophytes and decreasing overall water quality. Visual characterization and analysis shows that in central part - small extension of Lake Pērkonu is the main area, where sediment removal can be applied with expected sapropel amount -0.88 million $\mathrm{m}^{3}$. This area is approximately $-0.32 \mathrm{~km}^{2}$ with average water depth below $1 \mathrm{~m}$ and max depth $1.4 \mathrm{~m}$.

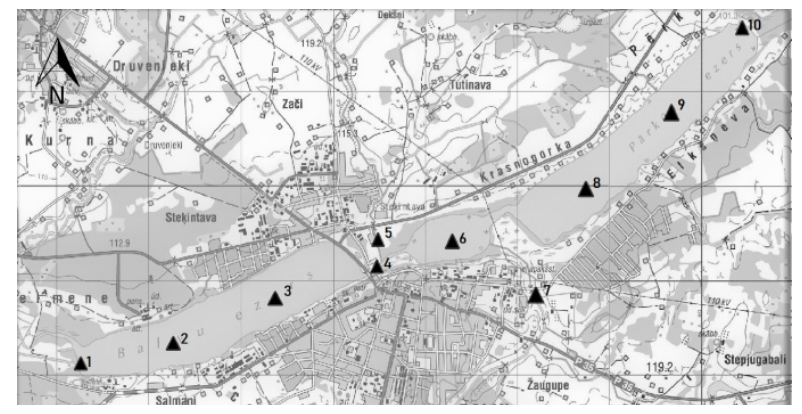

Fig. 1. Location of sediment sampling sites (1-5) in Balvu and Pērkonu Lakes.

Sampling of sediment cores was performed in the central part of the lakes and in coastal area. Full characterisation of samples from the central part of the lake was done, sample cores from the coastal area were used to obtain overall depth of lake sediment as well as and their genesis. Analysis of texture, elemental (C, N, P) and moisture content, presence of pollutants (metals, polyaromatic hydrocarbons, polychlorinated biphenyls), loss of ignition (LOI) and pH were determined. Sediments also called sapropel, gyttja was covering mineral soil layer which was mostly sand, gravel and rarely glacial till. Coring of sediments was done using a sediment sampler equipped with a $1.0 \mathrm{~m}$ long $(\mathrm{d}=5 \mathrm{~cm})$ tube. Every sample was put into a non-transparent airtight plastic bucket with a lid and stored at constant temperature $\left(+4 \mathrm{C}^{\circ}\right)$ to achieve in situ conditions during the storage.

Loss of ignition (LOI) method was applied for sediment analysis in order to estimate the moisture level and content of organic matter, carbonates and mineral matter in the sediments [17]. Moisture of sediments was determined after drying samples at $105^{\circ} \mathrm{C}$ in drying oven (Gallenkamp "Plus 2"). Content of organic and carbonate matter was analysed by incinerating the samples sequentially at $550^{\circ} \mathrm{C}$ for $4 \mathrm{~h}$ and at $900^{\circ} \mathrm{C}$ for $2 \mathrm{~h}$.

Total carbon and nitrogen concentration was determined using a $\mathrm{CN}$ elemental analyzer Eurovector EA3000 Series. Sediment $\mathrm{pH}$ was determined in $1 \mathrm{M} \mathrm{KCl}$ solution with HANNA Instruments HI2210 pH Meter.

Phosphorus determination in lake sediments. Sediments were dried at $105^{\circ} \mathrm{C}$ before digestion. Approximately $500 \mathrm{mg}$ of sample was weighed in a Teflon capsule and $9 \mathrm{~mL}$ of concentrated $\mathrm{HNO}_{3}$ and $1 \mathrm{~mL}$ of $30 \% \mathrm{H}_{2} \mathrm{O}_{2}$ was added to the sample. The capsule was sealed and placed in a microwave oven (Milestone Ethos Easy) and was digested at $200^{\circ} \mathrm{C}$ and 49 bar pressure for 15 minutes. After digestion the sample was filtered through a filter paper, diluted up to $50 \mathrm{~mL}$ with distilled water and phosphorus concentration was determined with ICP-OES (Thermo Scientific iCAP 7000 series).

Analysis of metal content in sediments. Approximately $1.0 \mathrm{~g}$ of dried sediment sample was weighed in a pressure durable teflon capsule and $25 \mathrm{~mL}$ of concentrated $\mathrm{HNO}_{3}$ (Enola) and $5 \mathrm{~mL}$ of $30 \% \mathrm{H}_{2} \mathrm{O}_{2}$ (Sigma-Aldrich) 
was added to the capsule. Samples were digested in a microwave extraction unit (Milestone ETHOS EASY) at $200^{\circ} \mathrm{C}, 49$ bar pressure for 20 minutes. A blank was made in each series of digestion. After digestion samples were cooled, filtered through a filter paper and diluted to 50 $\mathrm{mL}$ with distilled $\mathrm{H}_{2} \mathrm{O}$. Samples were then analysed with inductively coupled plasma spectrometer (ICP-OES) with optical detection (Thermo Scientific iCAP 7000 series).

Analysis of organic pollutants (PAH, PCB, hydrocarbons). For themeasurement of total hydrocarbons, fractions of hydrocarbons as well as $\mathrm{PAH}$, samples were extracted in double distilled hexane and analysed using gas-chromatography/mass spectrometry (Shimadzu GC2010 Plus). The method used for extracting the PCBs from sediments was modified from the US EPA Method [18]. Sediment (30 g) (analysis done in triplicate) was extracted for $8 \mathrm{~h}$ using the Soxhlet extraction unit with $200 \mathrm{ml}(1: 1)$ of $n$-hexane- $\mathrm{CH}_{2} \mathrm{Cl}_{2}$. Prepared extracts were analysed with gas-chromatograph (Shimadzu GC-2010 Plus). The sediment extracts were evaporated under a flow of nitrogen so that the dry residue corresponds to $20 \mathrm{mg}$. The dry residue of extract was dissolved in in pyridine (1500 $\mu \mathrm{L}$, Sigma-Aldrich). GC-MS analysis was performed using GC-2010 plus (Shimadzu, Japan). The column used was Restek Rxi ${ }^{\circledR}-5 \mathrm{MS}(30 \mathrm{~m} \times 0.25 \mathrm{~mm}$

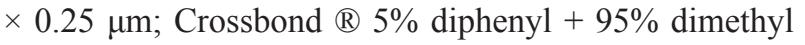
polysiloxane, Restek USA) with working temperature range 40 to $350{ }^{\circ} \mathrm{C}$. He (Helium) was used as carrier gas with a total flow rate of $10.8 \mathrm{~mL} \mathrm{~min}{ }^{-1}$ and column flow rate of $0.71 \mathrm{~mL}$ min- 1 flow rate. The split ratio was $1: 10$ and injection temperature $290^{\circ} \mathrm{C}$. The temperature programme used was: oven temperature $200{ }^{\circ} \mathrm{C}(2 \mathrm{~min})$ increased to $250{ }^{\circ} \mathrm{C}$ at the rate of $30{ }^{\circ} \mathrm{C} \mathrm{min}-1$ and held for $7 \mathrm{~min}$ then increased to $310^{\circ} \mathrm{C}$ at the rate of $10{ }^{\circ} \mathrm{C}$ $\min ^{-1}$ and kept for $14 \mathrm{~min}$. Injection of $1.0 \mu \mathrm{L}$ sample was performed using an autosampler. Identification and quantification of the compounds was done using the retention time (RT) of authentic standards, data acquisition and processing was done using Shimadzu LabSolutions 4.30 software.

Analysis of content of humic substances. The humic substances were extracted from lake sediments (10g) with $50 \mathrm{ml} 2 \% \mathrm{NaOH}$ solution and shaking for $24 \mathrm{~h}$. Then samples were purified using the procedures recommended by the International Humic Substances Society (IHSS) [19].

\section{RESULTS AND DISCUSSION}

Studied lakes are connected and they are part of Bolupe River watershed basin (total area - $936 \mathrm{~km}^{2}$ ). Water, nutrients, organic matter and suspended material are carried from eastern part of Latvia and lakes can be as archives for sediments and their fluxes. In this area $\sim 40$ $\%$ of land is used in agriculture and $\sim 10 \%$ are occupied by bogs and wetlands [20]. In Balvi municipality 65.6 $\%$ of agricultural lands are with installed drainage system. Land use and changes with drainage system due dredging of Bolupe River lead to decrease of water level in lakes by $1.5 \mathrm{~m}$, thus eutrophication increased [20]. One eutrophication parameters is macrophytes [4] and they cover only $15 \%$ of Lake Balvu, while Lake Pērkonu coverage reaches $50 \%$. In coastal area of Lake Pērkonu are indications of formation of wetlands (bogs and marshes). These changes are more visible in the central part of lakes, especially in small extension of Lake Pērkonu, where coverage of macrophytes exceeds $50 \%$ and average lake depth was less than $1 \mathrm{~m}$, which depends on season. In this particular area in Lake Pērkonu depth of lake sediments ranges from $0.5 \mathrm{~m}$ to $8 \mathrm{~m}$, therefore after removal of sediments the average depth could be significantly increased in this part of the lake and the occupation with macrophytes decreased. In result, water flowing into the Lake Balvu probably would have lower temperature and would be carrying less suspended material.

Dredging is one of methods that has been used for lake restoration, and removing the contaminated sediment from the lake bed. Dredging reduces the internal loading of nutrients by removing the upper sediment layer. This process has been successfully applied on peat lake sediments in the Netherlands [14]. It has also been successfully used in Sweden, with lakes showing reduced cyanobacteria biomass in the years following sediment removal [15]. There can be side effects for sediment removal such as: changes in sediment stability and impacting neighbour sediment structures, significant impacts on water quality (by releasing organic matter and nutrients), disturbed ecosystems by removing and killing organisms which can play an important role at the base of aquatic food chains [21]. If the sediments are polluted, toxic chemicals such as heavy metals and other pollutants can release back into the water. In addition to changes of water flow, also impact to the fish fauna can be observed, in deeper lakes the area is more accessible to larger predators, not only small fish [22].

In Lake Balvu high biomass of cyanobacteria (algae blooms) can be observed, while Lake Pērkonu suffers from stress caused by decreased oxygen concentrations in winter period. The extension of Lake Pērkonu has no significant role in fishery, because of lack of healthy benthic fauna. On one hand, excavation could change the ecosystem of these lakes (or part where applied), but on the other hand, as open lakes they can be more resilient to changes of ecosystem after sediment removal [23]. Moreover the actual excavation and changes of ecosystem can reach only $14 \%$ from total area of Lake Pērkonu if applied only on particular extension of lake.

TABLE I. ELEMENTAL COMPOSITION AND THEIR RELATIONS OF SEDIMENT COVER IN BALVu AND PERKonu LaKes

\begin{tabular}{|c|c|c|c|c|c|}
\hline $\begin{array}{c}\text { Sam- } \\
\text { pl-ing } \\
\text { point No. }\end{array}$ & $\begin{array}{c}\mathbf{N}, \\
\mathbf{\%}\end{array}$ & $\mathbf{C}, \mathbf{\%}$ & $\begin{array}{c}\mathbf{P}, \mathbf{g} / \\
\mathbf{k g}\end{array}$ & $\mathbf{C} / \mathbf{N}$ & $\mathbf{C : N : P}$ \\
\hline 1 & 1.08 & 18.54 & 0.99 & 17.17 & $187: 11: 1$ \\
\hline 2 & 1.20 & 18.70 & 1.21 & 15.58 & $155: 10: 1$ \\
\hline 3 & 1.43 & 23.74 & 0.96 & 16.60 & $247: 15: 1$ \\
\hline 4 & 0.59 & 8.45 & 0.90 & 14.32 & $94: 7: 1$ \\
\hline 5 & 0.91 & 12.40 & 1.29 & 13.63 & $96: 7: 1$ \\
\hline
\end{tabular}


Described benefits of sediment removal on Lake Pērkonu and possible improvements of lake ecosystem shows importance of sediment characterization before activities connected with accumulated sediments. Texture of sediment profiles was homogenous and similar with relatively minor differences compared to the max depth of sample cores. With increasing depth the content of organic matter in sediments increased from $19.09 \%$ to $73.60 \%$. These changes indicate presence of humification processes in sediments [24], water flow through lakes, and anthropogenic impact which affected sedimentation rates. Deepest parts of the lake bed in past were with more stagnant water regime, therefore with higher sedimentation rates (especially small, suspended particles) could be observed. Upper layers indicate impact of human actions in watershed basin and in coastal area with significantly increased ash content and proportion of allochthonous material (Table 2). For example, if C/N ratio (Table 1) 6 - 9 corresponds to plankton, then $\mathrm{C} / \mathrm{N}$ ratios $15-20$ corresponds to terrestrial vascular plants and their derivates in sediments and about 39.4 for macrophyte materials [25]. In surface waters $\mathrm{N}: \mathrm{P}$ ratio is well characterized [26], [27] and indicating increased loads of phosphorus in studied lakes and their sediments, therefore accelerating eutrophication of lakes and $\mathrm{P}$ ability to resolve from sediments in anoxic conditions [26].

TABLE II. CONTENT OF ORGANIC MATTER, ASH AND Moisture In SEDIMENTS of BALVU AND PĒrkONU

LAKES

\begin{tabular}{|c|c|c|c|c|}
\hline $\begin{array}{c}\text { Sam- } \\
\text { pl-ing } \\
\text { point } \\
\text { No. }\end{array}$ & $\begin{array}{c}\text { Depth, } \\
\text { cm }\end{array}$ & $\begin{array}{c}\text { Mois-ture, } \\
\%\end{array}$ & $\underset{\%}{\text { Ash }}$ & $\begin{array}{c}\text { Organic } \\
\text { matter, } \\
\%\end{array}$ \\
\hline \multirow{3}{*}{1} & $0-10$ & 84.37 & 70.66 & 29.33 \\
\hline & $90-100$ & 89.64 & 53.16 & 46.84 \\
\hline & $190-200$ & 90.32 & 44.01 & 55.99 \\
\hline \multirow{4}{*}{2} & $10-20$ & 86.95 & 66.41 & 33.59 \\
\hline & $110-130$ & 89.86 & 48.19 & 51.80 \\
\hline & $280-290$ & 91.43 & 48.57 & 51.43 \\
\hline & $350-360$ & 90.46 & 34.16 & 65.84 \\
\hline \multirow{6}{*}{3} & $10-30$ & 84.32 & 57.49 & 42.51 \\
\hline & $220-230$ & 91.03 & 41.64 & 58.36 \\
\hline & $360-360$ & 91.65 & 39.07 & 60.93 \\
\hline & $440-450$ & 91.68 & 41.07 & 58.93 \\
\hline & $590-600$ & 91.15 & 39.15 & 60.85 \\
\hline & $700-710$ & 91.90 & 26.40 & 73.60 \\
\hline \multirow{5}{*}{4} & $10-20$ & 75.68 & 80.91 & 19.09 \\
\hline & $120-130$ & 86.35 & 60.64 & 39.36 \\
\hline & $250-260$ & 81.05 & 68.73 & 31.27 \\
\hline & $400-410$ & 72.46 & 83.39 & 16.61 \\
\hline & $420-430$ & 28.44 & 91.22 & 0.78 \\
\hline
\end{tabular}

\begin{tabular}{|c|c|c|c|c|}
\hline \multirow{4}{*}{5} & $10-30$ & 85.50 & 73.93 & 26.07 \\
\cline { 2 - 5 } $\mathbf{5}$ & $140-150$ & 89.22 & 57.00 & 43.00 \\
\cline { 2 - 5 } & $270-280$ & 88.42 & 55.50 & 44.50 \\
\cline { 2 - 5 } & $350-360$ & 88.33 & 49.15 & 50.85 \\
\hline
\end{tabular}

High C:N:P ratio (102-202:6-16:1) is typically associated with agricultural runoff [28], [29], which also can be observed in studied lakes, which can be affected by their location in hydrological cycle and catchment area (Table 1). The upper part of sediments from Lake Balvu significantly differs from Lake Pērkonu based on their $\mathrm{C}: \mathrm{N}: \mathrm{P}$ ratios demonstrating influence of allochthonous material sources in last decades in Lake Pērkonu. These differences support described hypothesis of sediment removal in the extension of Lake Pērkonu, because increased eutrophication can lead to changes of Lake Balvu.

TABLE III. CONTENT OF HUMIC ACIDS, CARBONATES

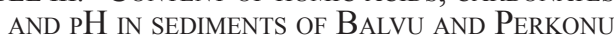

LAKES

\begin{tabular}{|c|c|c|c|c|}
\hline $\begin{array}{c}\text { Sam- } \\
\text { pl-ing } \\
\text { point } \\
\text { No. }\end{array}$ & $\begin{array}{c}\text { Depth, } \\
\mathbf{c m}\end{array}$ & $\mathbf{p H}$ & $\begin{array}{c}\text { Car- } \\
\text { bon-ates, } \\
\text { \% }\end{array}$ & $\begin{array}{c}\text { Content } \\
\text { of humic } \\
\text { acids, mg/g }\end{array}$ \\
\hline \multirow{4}{*}{1} & $0-10$ & 6.72 & 2.55 & 256.64 \\
\cline { 2 - 5 } & $90-100$ & 7.07 & 2.34 & 427.02 \\
\cline { 2 - 5 } & $190-200$ & 6.97 & 3.12 & 358.15 \\
\hline \multirow{4}{*}{2} & $10-20$ & 6.89 & 2.60 & n.a. \\
\cline { 2 - 5 } & $110-130$ & 7.25 & 3.09 & n.a. \\
\cline { 2 - 5 } & $280-290$ & 6.82 & 3.12 & n.a. \\
\cline { 2 - 5 } & $350-360$ & 6.88 & 4.34 & n.a. \\
\hline \multirow{4}{*}{3} & $10-30$ & 6.30 & 2.96 & 278.35 \\
\cline { 2 - 5 } & $220-230$ & 7.0 & 2.78 & 451.97 \\
\cline { 2 - 5 } & $360-360$ & 6.59 & 2.45 & 385.43 \\
\cline { 2 - 5 } & $440-450$ & 6.80 & 2.85 & 413.90 \\
\cline { 2 - 5 } & $590-600$ & 6.81 & 3.84 & 425.78 \\
\cline { 2 - 5 } & $700-710$ & 6.71 & 4.40 & 495.87 \\
\hline \multirow{4}{*}{4} & $10-20$ & 6.58 & 2.04 & n.a. \\
\cline { 2 - 5 } & $120-130$ & 6.82 & 2.05 & n.a. \\
\cline { 2 - 5 } & $250-260$ & 6.98 & 2.50 & n.a. \\
\cline { 2 - 5 } & $400-410$ & 7.96 & 3.71 & n.a. \\
\hline & $420-430$ & 7.07 & 0.33 & n.a. \\
\hline \multirow{4}{*}{5} & $10-30$ & 6.7 & 3.14 & 291.11 \\
\hline \multirow{4}{*}{5} & $140-150$ & 6.89 & 3.28 & 673.02 \\
\hline & $270-280$ & 7.09 & 3.90 & 347.72 \\
\hline & $350-360$ & 6.98 & 3.86 & 254.90 \\
\hline
\end{tabular}

n.a. - concentration not analysed.

Analysis of biological composition of sediments demonstrate, previously described factors about sedimentation, eutrophication, overgrowing with 
macrophytes and formation of wetlands in coastal area. Early lake ecosystem can be described by the presence of organic matter in the bottom layers which is mainly formed from blue-green algae, green algae, plants and water animals. Upper part of sediments shows large proportion of vascular plants and macrophytes (63-78\%), diatoms $(11-23 \%)$ and up to $21 \%$ green algae. Small proportion of macrophytes by biological composition and $\mathrm{C} / \mathrm{N}$ ratio are due to relatively high average depth $(>2 \mathrm{~m})$ in studied lakes, especially before decreasing of water level in lakes by $1.5 \mathrm{~m}$. In the middle part of sediment profiles in all studied lakes were found biological composition that corresponds to fen peat. There are several factors influencing this pattern, and one of them could be presence of organic material form coastal area and catchment area. Other aspect could the climatic events 4000 years BP, when the water level was extremely decreased, because of the cold and dry climate [30]. Content of humic substances (Table 3) did not show clear pattern in sediments of studied lakes due to different climatic conditions and biological composition of sediments as well as their different accumulation rates and humification. It can be influenced by different rates of humification [31], [32], available material amount, sources included in those reactions and possible washing out of humic substances due to run-off hydrological regime [30]. Presence of water flow and streams in lakes in past can be determined in bottom part of sediments schistous texture of sediments is present (sand, gravel, clay), which is not detected in all sampling, indicating areas with more intense water flowrates in the past.

TABLE IV. TOTAL HYDROCARBONS, POLYCYCLIC AROMATIC HYDROCARBON (PAH) AND POLYCHLORINATED BIPHENYLS (PCB) IN SEDIMENTS OF

Balvu and Perkonu Lakes. Units represent mG OR MG OF SUBSTANCES FOUND IN KG OF SEDIMENT

\begin{tabular}{|c|c|c|c|c|}
\hline $\begin{array}{c}\text { Sam- } \\
\text { pling } \\
\text { No. }\end{array}$ & $\begin{array}{c}\text { Depth, } \\
\text { cm }\end{array}$ & $\begin{array}{c}\text { Total } \\
\text { hydro- } \\
\text { car- } \\
\text { bons, } \\
\text { mg/kg }\end{array}$ & $\begin{array}{c}\text { Poly- } \\
\text { cyclic } \\
\text { aromatic } \\
\text { hydro- } \\
\text { carbons, } \\
\mu \mathrm{g} / \mathrm{kg}\end{array}$ & $\begin{array}{l}\text { Poly- } \\
\text { chlori- } \\
\text { nated } \\
\text { biphe- } \\
\text { nyls, } \mu \text { g/ } \\
\text { kg }\end{array}$ \\
\hline \multirow{2}{*}{1} & $0-10$ & 63 & 136 & 3.2 \\
\hline & $100-110$ & 123 & 41.5 & n.a. \\
\hline \multirow{2}{*}{2} & $10-20$ & 94 & 226 & 10.3 \\
\hline & $110-130$ & 97 & 100 & n.a. \\
\hline \multirow{2}{*}{3} & $10-30$ & 65 & 631 & 15.1 \\
\hline & $200-220$ & 43 & 112 & n.a. \\
\hline \multirow{2}{*}{4} & $10-30$ & 14 & 1278 & 1.6 \\
\hline & $120-140$ & 28 & 131 & n.a. \\
\hline \multirow{2}{*}{5} & $10-30$ & 56 & 633 & $<0.5$ \\
\hline & $130-150$ & 31 & 65 & n.a. \\
\hline
\end{tabular}

n.a. - concentration not analysed.

The studied lakes are surrounded by urban territories and with surface runoff typical pollutants from there can be detected. Therefore presence of heavy metals, total amount of oil including polycyclic aromatic hydrocarbons (PAHs) and polychlorinated biphenyls (PCBs) were analyzed. Analysis of sediments show that total amount of oil products does not exceed concentrations found in natural conditions [33]. PCB's are directly correlated to human activities, the main sources of PCBs emissions into the environment can be divided into 5 groups: 1) production of PCBs and products (equipment) containing PCBs; 2) use of products containing PCBs; 3) utilization of PCBs and materials containing PCBs; 4) emission from reservoirs polluted by PCBs; 5) thermal processes [34]. PCBs were analysed in 5 samples of the upper sediment (Table 4). Although individual compounds of PCB's such as PCB-52 (points 1-3) and PCB-28 (points 2-3) have exceed minimal reqs $(1 \mu \mathrm{g} / \mathrm{kg})$, these sediments could not be classified as polluted. As described above, possible sources of PCBs in lakes can be emissions from fuels combustion, transportation and urban runoff, in this case especially from road and streets pavement [35] [37] and landfills [38] in the catchment area of studied lakes. PAH's in studied sites show different pattern than PCBs. Elevated concentrations of PAHs were found in Lake Balvi in comparison to Lake Pēkonu, where the coastal area is less urbanized. Concentration of PAH's are elevated only in upper sediment layer due to their nature [39] and low solubility in water [33]. Increased $\mathrm{PAH}$ concentrations in Lake Balvi were not reaching hazardous levels, also the government set maximum concentrations were not exceeded (Table 4).

TABLE V. CONTENT OF HEAVY METALS (MG/KG) IN SEDIMENTS of Balvu and Pērkonu Lakes

\begin{tabular}{|c|c|c|c|c|c|}
\hline $\begin{array}{c}\text { Sam- } \\
\text { pl-ing } \\
\text { No. }\end{array}$ & $\underset{\text { cm }}{\text { Depth, }}$ & $\mathbf{Z n}$ & $\mathrm{Cu}$ & $\mathrm{Cr}$ & $\mathbf{N i}$ \\
\hline \multirow{2}{*}{1} & $0-10$ & 165 & 18.1 & 18.0 & 19.5 \\
\hline & $100-110$ & 263 & 27.9 & 19.4 & 22.7 \\
\hline \multirow{2}{*}{2} & $10-20$ & 221 & 17.4 & 18.9 & 26.0 \\
\hline & $110-130$ & 335 & 41.7 & 17.8 & 40.4 \\
\hline \multirow{3}{*}{3} & $10-30$ & 166 & 17.8 & 17.3 & 17.4 \\
\hline & $200-220$ & 271 & 36.5 & 18.6 & 25.3 \\
\hline & $700-710$ & 123 & 20.3 & 9.7 & 23.8 \\
\hline \multirow{2}{*}{4} & $10-30$ & 130 & 15.9 & 15.9 & 14.4 \\
\hline & $120-140$ & 201 & 19.4 & 17.0 & 17.6 \\
\hline \multirow{3}{*}{5} & $10-30$ & 202 & 25.6 & 23.1 & 22.3 \\
\hline & $130-150$ & 238 & 24.3 & 17.4 & 23.6 \\
\hline & $350-360$ & 169 & 41.8 & 30.3 & 34.6 \\
\hline
\end{tabular}


TABLE VI. CONTENT OF HEAVY METALS (MG/KG) IN SEDIMENTS OF BALVU AND PērkKONu LAKes

\begin{tabular}{|c|c|c|c|c|}
\hline $\begin{array}{c}\text { Sam- } \\
\text { pl-ing } \\
\text { No. }\end{array}$ & $\begin{array}{l}\text { Depth, } \\
\text { cm }\end{array}$ & $\mathbf{P b}$ & As & Cd \\
\hline \multirow{2}{*}{1} & 0-10 & 9.8 & 10.60 & 1.44 \\
\hline & $100-110$ & 2.7 & 9.67 & 1.80 \\
\hline \multirow{2}{*}{2} & $10-20$ & 8.0 & 14.50 & 2.27 \\
\hline & $110-130$ & 6.3 & 6.04 & 1.52 \\
\hline \multirow{3}{*}{3} & $10-30$ & 13.1 & 11.50 & 1.40 \\
\hline & $200-220$ & 6.7 & 9.60 & 1.92 \\
\hline & $700-710$ & 2.2 & 8.00 & 0.25 \\
\hline \multirow{2}{*}{4} & $10-30$ & 23.6 & 5.37 & 0.89 \\
\hline & $120-140$ & 2.4 & 8.73 & 0.97 \\
\hline \multirow{3}{*}{5} & $10-30$ & 35.4 & 14.90 & 1.46 \\
\hline & $130-150$ & 4.6 & 10.50 & 1.60 \\
\hline & $350-360$ & 4.1 & 8.60 & 0.21 \\
\hline
\end{tabular}

Higher concentrations of heavy elements in sediments were detected in upper layer corresponding to possible anthropogenic impact and in deeper located sediments corresponding to metals carried with groundwater (Tables $5,6)$. Sources of metals in sediments can include airborne sources, solid waste, sludges, soils and direct groundwater contamination [40]. Concentrations of metals in the studied lakes were comparable with other studies done in Latvia [41] - [43]. In comparison to other lakes with no or insignificant human impact, there are slightly elevated concentrations of $\mathrm{Zn}, \mathrm{Cd}$, and some cases - Ni. Zinc is one of the most mobile heavy metals in surface waters and groundwater and can be absorbed by sediments or suspended solids, including hydrous iron and manganese oxides, clay minerals, and organic matter. Most common cadmium sources can be the mining of sulphide ores of lead, zinc and copper and the disposal of cadmiumcontaining wastes. Sorption of $\mathrm{Cd}$ is influenced by the cation exchange capacity of clays, carbonate minerals, and organic matter present in sediments [40]. Concentrations of studied metals $(\mathrm{Zn}, \mathrm{Cu}, \mathrm{Pb}, \mathrm{Cr}, \mathrm{Ni})$ in lake sediments are attributed to natural factors such as geochemical properties of bedrock and soil [26], but such metals as $\mathrm{Pb}$, As, Cd shows presence of industrial activities (Table 6). As, Cd have no similar patterns or correlation with ash and organic matter content of sediments as other metals. For these metals sources are connected with anthropogenic impact, but for $\mathrm{Pb}$ sources can be mixed. Possible sources of these metals also can be atmospheric deposition [44], surface runoff from urban territories and landfills. The bottom layers showed lower ash content, which can be attributed to lack of anthropogenic influence (Table 2).

\section{CONCLUSIONS}

Water quality, watershed basin and urbanization of coastal area are key factors from the perspective of freshwater management; however, studied lakes show presence of human impact. Studied lakes show indications of eutrophication which is an ongoing process. Therefore, without using the offered ecosystem services it is also important to apply available knowledge and technologies to reduce human impact on lakes and catchment area, or even reconstruct the environment. Reducing the loads of nutrients in lakes is important, another aspect, due to possible climate changes and influenced hydrological regime, is keeping stable water level in the studied lakes. There are no options to raise water levels to the levels seen before dredging of River Bolupe, in addition the biomass production in these eutrophic lakes lead to decrease of water depth due to sedimentation. As most effective solution for the studied lakes, the sediment excavation can be considered. By performing excavation, the average and maximum depth of water in Lake Pērkonu will increase, meanwhile reducing the available amount of phosphorus. Sediment removal in the extension of Lake Pērkonu will reduce coverage of macrophytes, and possibly improve the water quality of Lake Balvu. Despite the discovered human impact on quality of sediment, excavated sediment can be successfully used for different purposes, for example, as fertilizer. Sediment analysis show possible pollution sources which can be managed by the municipality.

\section{AcKNowledgements}

This work was supported by University of Latvia grant "Sustainable use of nature resources in the context of climate changes. "No.AAP2016/B041".

\section{REFERENCES}

[1] Y. Yuan, G. Zeng, J. Liang, L. Huang, S. Hua, F. Li, Y. Zhu, H. Wu, J. Liu, X. He, Y. He, "Variation of water level in Dongting Lake over a 50-year period:Implications for the impacts of anthropogenic and climatic factors," Journal of Hydrology, 525, pp. 450-456, 2015 .

[2] M. Klavins, I. Kokorite, M. Jankevica, V. Rodinovs, L. Dreijalte, "Reconstruction of Anthropogenic Impact Intensity Changes during Last 300 Years in Lake Engure Using Analysis of Sedimentary Records," Environmental and Climate Technologies, 7, pp. 66-71, 2011.

[3] K. Stankevica, A. Pujate, L. Kalnina, M. Klavins, A. Cerina, A. Drucka, "Records of the anthropogenic influence on different origin small lake sediments of Latvia," Baltica, 28(2), pp. 135-150. 2015.

[4] G. Springe, I. Druvietis, E. Parele, "The plankton and benthos communities of the lagoon lake Engures (Engure), Latvia," Proceedings of Latvian Academy of Sciences, B, 54(5), pp. 164-169, 2000.

[5] J. Rosińska, M. Rybak, R. Gołdyn, "Patterns of macrophyte community recovery as a result of the restoration of a shallow urban lake," Aquatic Botany, 138, pp. 45-52, 2017.

[6] S. Trajanovska, M. Talevska, A. Imeri, S.C. Schneider, “Assessment of littoral eutrophication in Lake Ohrid by submerged macrophytes," Biologia, 69(6), pp. 756-764, 2014.

[7] L.T.T Kissoon, D.L. Jacob, M.A Hanson, B.R. Herwig, S.E. Bowe, M.L. Ottea, "Macrophytes in shallow lakes: relationships with water, sediment and watershed characteristics," Aquat. Bot., 109, pp. 39-48, 2013.

[8] J. Grochowska, R. Brzozowska, M. Łopata, J. Dunalska, "Influence of restoration methods on the longevity of changes in the thermal and oxygen dynamics of a degraded lake," Oceanol. Hydrobiol. Stud., 44 (1), pp. 18-27, 2015.

[9] B.M. Spears, S. Meis, A. Anderson, M. Kellou, "Comparison of phosphorus (P) removal properties of materials proposed for the 
control of sediment p release in UK lakes," Science of the Total Environment, 442, pp. 103-110, 2013.

[10] S.L. Aalto, J. Saarenheimo, J. Ropponen, J. Juntunen, A.J. Rissanen, M. Tiirola, "Sediment diffusion method improves wastewater nitrogen removal in the receiving lake sediments," Water Research, 138, pp. 312-322, 2018.

[11] J. Rosińska, A. Kozak, R. Dondajewska, K. Kowalczewska-Madura, R. Gołdyn, "Water quality response to sustainable restoration measures - Case study of urban Swarzędzkie Lake.” Ecological Indicators, 84, pp. 437-449, 2018.

[12] J. van Wichelen, S. Declerck, K. Muylaert, I. Hoste, V. Geenens, J. Vandekerkhove, "The importance of drawdown and sediment removal for the restoration of the eutrophied shallow lake Kraenepoel (Belgium)," Hydrobiologia, 584, pp. 291-303, 2007.

[13] K. Stankevica, J. Burlakovs, M. Klavins, Z. Vincevica-Gaile, "Environmental and economic aspects of small freshwater lake sustainable use: Lake Pilvelis example," In: Proceedings of 14th SGEM GeoConference on Science and Technologies in Geology, Exploration and Mining, 5(3), pp.127-134, 2014.

[14] J. van der Does, P. Verstraelen, P. Boers, J. van Roestel, R. RoiJACKers, G. Moser, "LAKE RESTORATION WITH AND WITHOUT DREDGING of P-enriched upper sediment layers," Hydrobiologia, 233(1), pP. 197-210, 1992

[15] M. LÜrling, E. J. FAassen, "CONTROlling toxic Cyanobacteria: EFFECTS OF DREDGING AND P-BINDING CLAY ON CYANOBACTERIA AND MICROCYSTINS," WATER RESEARCH, 46(5), PP. 1447-1459. 2012

[16] O. Purmalis, J. Burlakovs, "Reviving prospects for lake restoration-investigating the geochemistry of Lake Alūksne sediments", Research for Rural Development, 1, pp. 145-152, 2017

[17] O. Heiri, A.F. Lotter, G. Lemcke, "Loss on ignition as a method for estimating organic and carbonate content in sediments: reproducibility and comparability of results," Journal of Paleolimnology, 25 , pp. 101-110, 2001

[18] USEPA, "Method 8081A. Organochlorine Pesticides by Gas Chromatography. Revision 1", Washington DC: US Environmental Protection Agency, 1996.

[19] K.H. Tan, "Soil sampling, preparation, and analysis - second edition,” N.Y.: Taylor \& Francis group, 623, 2005.

[20] Balvu novada dome, "Balvu novada teritorijas plānojums2012.-2023. gadam," 1.sējums, 1. redakcija., Balvi, 2011.

[21] A. Covich, M. Palmer, T. Crowl, "The Role of Benthic Invertebrate Species in Freshwater Ecosystems: Zoobenthic species influence energy flows and nutrient cycling," BioScience, 49/2, pp. $119-127,1999$

[22] E.Aleksejevs, J.Birzaks, "Long-term Changes in the Ichthyofauna of Latvia's Inland Waters," Environmental and Climate TeChNologies, vol.7, PP. 9-18, 2011.

[23] R. Reice, R.Wissmar, R. Naiman, "Disturbance regimes, resilience, and recovery of animal communities and habitats in lotic ecosystems," Environmental Management, 14(5), pp. 647-659, 1990.

[24] P.A. Meyers, R. Ishiwatari, "Lacustrine organic geochemistry-an overview of indicators of organic matter sources and diagenesis in lake sediments," Org. Geochem., Vol. 20(7), pp. 867-900, 1993.

[25] D. M. Mahapatra, H.N. Chanakya, T. V. Ramachandra, "C:N ratio of Sediments in a sewage fed Urban Lake," International Journal of Geology, 3(5), 2011

[26] M. Klavins, V. Rodinovs, I. Kokorite, "Chemistry of surface waters in Latvia," Riga: University of Latvia, 2002.

[27] R.W. Sterner, “C:N:P stoichiometry in Lake Superior: freshwater sea as end member," Inland Waters, 1, pp. 29-46, 2011.

[28] G. de la Lanza-Espino, F.J.lores-Verdugo, S. Hernández-Pulido, I. Penié-Rodríguez, "Concentration of nutrients and $\mathrm{C}: \mathrm{N}: \mathrm{P}$ ratios in surface sediments of a tropical coastal lagoon complex affected by agricultural runoff," Universidad y Ciencia, 27, pp. 145-155, 2011.

[29] G. de la Lanza-Espino, L.A. Soto, "C:N:P Molar Ratios, Sources and ${ }^{14} \mathrm{C}$ Dating of Surficial Sediments from the NW Slope of Cuba." PLoS ONE, 10(6), pp. 1-19, 2015.

[30] K. Stankevica, L. Kalnina, M. Klavins, A. Cerina, L. Ustupe, E. Kaup, "Reconstruction of the Holocene Palaeoenvironmental Conditions Accordingly to the Multiproxy Sedimentary Records from Lake Pilvelis, Latvia." Quaternary International, 386, pp. 102-15, 2015

[31] O. Purmalis, M. Klavins "Formation and changes of humic acid properties during peat humification process within ombrotrophic bogs," Open Journal of Soil Science, 2, pp. 100-110, 2012.

[32] M. Kḷaviņš, O. Purmalis, "Surface activity of humic substances depending on their origin and humification degree," Proceedings of Latvian Academy of Sciences, Section B, 67(6), pp. 493-499, 2013.

[33] H.I. Abdel-Shafy, M.S.M. Mansour, “A review on polycyclic aromatic hydrocarbons: Source, environmental impact, effect on human health and remediation," Egyptian Journal of Petroleum, 25, pp. 107-123, 2016.

[34] S. Kakareka, T. Kukharchyk, "EMEP/CORINAIR Guidebook: Sources of polychlorinated biphenyls emissions," Minsk: National Academy of Sciences of Belarus, 2005.

[35] B.J. Mahler, P.C. van Metre, W. T. Foreman, "Concentrations OF POLYCYCLIC AROMATIC HYDROCARBONS (PAHS) AND AZAARENES IN RUNOFF FROM COAL-TAR- AND ASPHALT-SEALCOATED PAVEMENT," ENVIRONMENTAL Pollution, Vol. 188, PP. 81-87, 2014.

[36] C.A. Alves, A.M.P. Vicente, J. Gomes, T. Nunes, M. Duarte B.A.M. Bandowe, "Polycyclic aromatic hydrocarbons (PAHs) and their derivatives (oxygenated-PAHs, nitrated-PAHs and azaarenes) in size-fractionated particles emitted in an urban road tunnel," Atmospheric Research, vol. 180, pp. 128-137, 2016.

[37] J. Zhang, R. Li, X. Zhang, Y. Bai, P. Cao , P. Hua, "Vehicular contribution of PAHs in size dependent road dust: A source apportionment by PCA-MLR, PMF, and Unmix receptor models," Science of The Total Environment, vol. 649, pp. 1314-1322, 2019.

[38] K. Vorkamp, "An overlooked environmental issue? A review of the inadvertent formation of PCB-11 and other PCB congeners and their occurrence in consumer products and in the environment," Science of The Total Environment, 541, pp. 1463-1476, 2016.

[39] D. Dąbrowska, A. Kot-Wasik, J. Namieśnik, ”Stability Studies of Selected Polycyclic Aromatic Hydrocarbons in Different Organic Solvents and Identification of Their Transformation Products," Polish J. of Environ. Stud., 17(1), pp. 17-24, 2008.

[40] C.R. Evanko, D.A. Dzombak, "Remediation of Metals-Contaminated Soils and Groundwater," Pittsburg: Ground-Water Remediation Technologies Analysis Center, 1997.

[41] M. Kḷaviņš, A. Briede, I. Kḷaviņa, V. Rodinov, "Metals in sediments of lakes in Latvia," Environment International, 21(4), pp. 451-458, 1995.

[42] M. Klavins, M. Vircavs, "Metals in sediments of inland water of Lativa,” Boreal environmental research, 6, pp. 297-306, 2001.

[43] M. Klavins, I. Kokorite, M. Jankevica, J. Mazeika, V. Rodinov, "Trace elements in sediments of lakes in Latvia," Recent Researches in Geography, Geology, Energy, Environment and Biomedicine, pp. 43-47, 2011

[44] W. Schröder, R. Pesch, A. Hertel, S. Schonrock, H. Harmens, G. Mills, I. Ilyin, "Correlation between atmospheric deposition of Cd, $\mathrm{Hg}$ and $\mathrm{Pb}$ and their concentrations in mosses specified for ecological land classes covering. Europe." Atmospheric Pollution Research, 4, pp. 267-274, 2013. 